\title{
Eastern Pigmy Blue, Brephidium isophthalma pseudofoea (Morrison) (Insecta: Lepidoptera: Lycaenidae) ${ }^{1}$
}

Donald W. Hall and Jerry F. Butler ${ }^{2}$

\section{Introduction}

The eastern pigmy blue is our smallest eastern butterfly. It is found near saltwater -- particularly in salt marshes where its host plants occur.

\section{Distribution}

The eastern pigmy blue is found in coastal areas from southern South Carolina to southern central Florida on the Atlantic coast, from the tip of peninsular Florida up the Gulf coast through the Big Bend Area, and from the western panhandle of Florida to eastern Louisiana.

\section{Description}

The wingspread of the adult is 9 to $11 \mathrm{~mm}$. Undersides of wings are brown with a row of submarginal black spots with white highlights and are patterned with numerous white dashes and a submedian row of white circles. Upper sides of wings are brown with black spots without highlights.

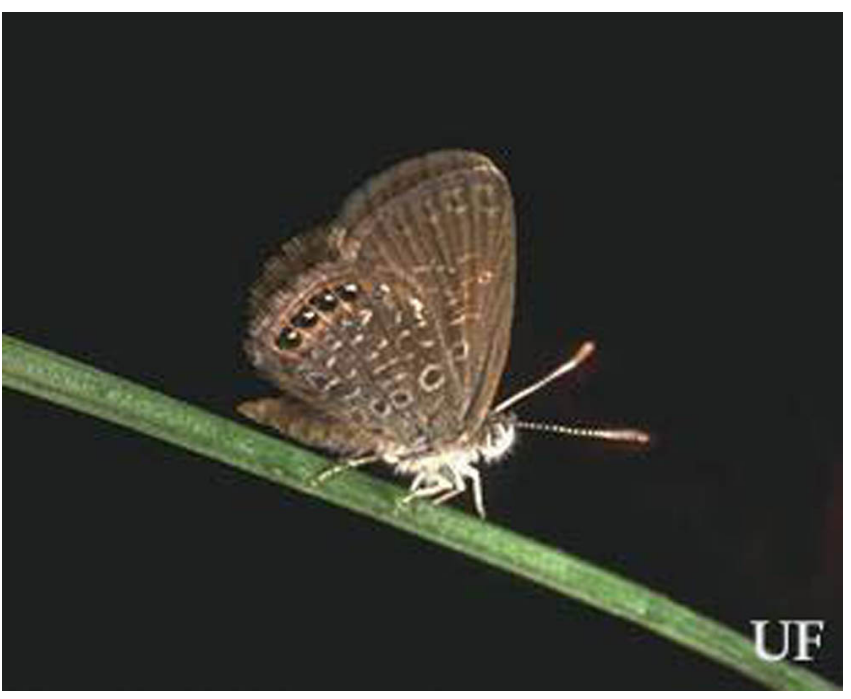

Figure 1. Adult eastern pigmy blue, Brephidium isophthalma pseudofoea (Morrison). Credits: Jerry F. Butler, University of Florida

Eastern pigmy blue eggs are pale blue-green. The larvae are green with small white tubercles that closely match the pattern on the glasswort host plant. Pupae are variable but usually yellow-brown with darker brown dots.

1. This document is EENY-107, one of a series of the Entomology and Nematology Department, Florida Cooperative Extension Service, Institute of Food and Agricultural Sciences, University of Florida. Original publication date August 1999. Reviewed May 2003. Visit the EDIS Web Site at http://edis.ifas.ufl.edu.

2. Donald W. Hall, professor and Jerry F. Butler, professor, Entomology and Nematology Department, Institute of Food and Agricultural Sciences, University of Florida, Gainesville, FL.

The Institute of Food and Agricultural Sciences (IFAS) is an Equal Opportunity Institution authorized to provide research, educational information and other services only to individuals and institutions that function with non-discrimination with respect to race, creed, color, religion, age, disability, sex, sexual orientation, marital status, national origin, political opinions or affiliations. U.S. Department of Agriculture, Cooperative Extension Service, University of Florida, IFAS, Florida A. \& M. University Cooperative Extension Program, and Boards of County Commissioners Cooperating. Larry Arrington, Dean 


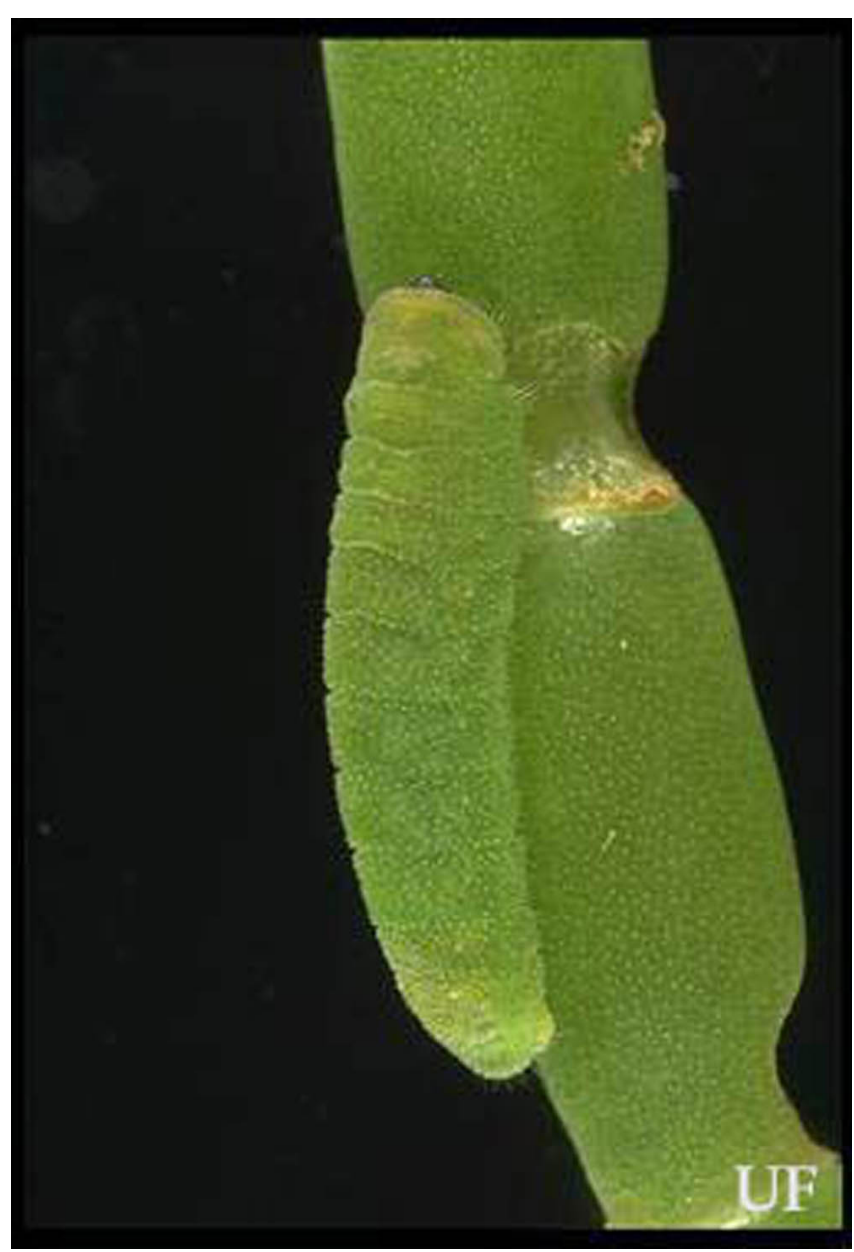

Figure 2. Larva of the eastern pigmy blue, Brephidium isophthalma pseudofoea (Morrison). Credits: Jerry F. Butler, University of Florida

\section{Life Cycle}

There are many flights all year in Florida. Males patrol near host plants and courtship occurs in late afternoon. The primary larval host plant is annual glasswort, Salicornia bigelovii Torr.

(Chenopodiaceae). Perennial glasswort, Salicornia perennis Mill. and saltwort, Batis maritima $\mathrm{L}$. (Bataceae) also may be used.

\section{Selected References}

Gerberg, E.J. and R.H. Arnett. 1989. Florida Butterflies. National Science Publications, Inc. Baltimore, MD.

Opler, P.A. and G.O. Krizek. 1984. Butterflies East of the Great Plains. The Johns Hopkins University Press. Baltimore, MD.

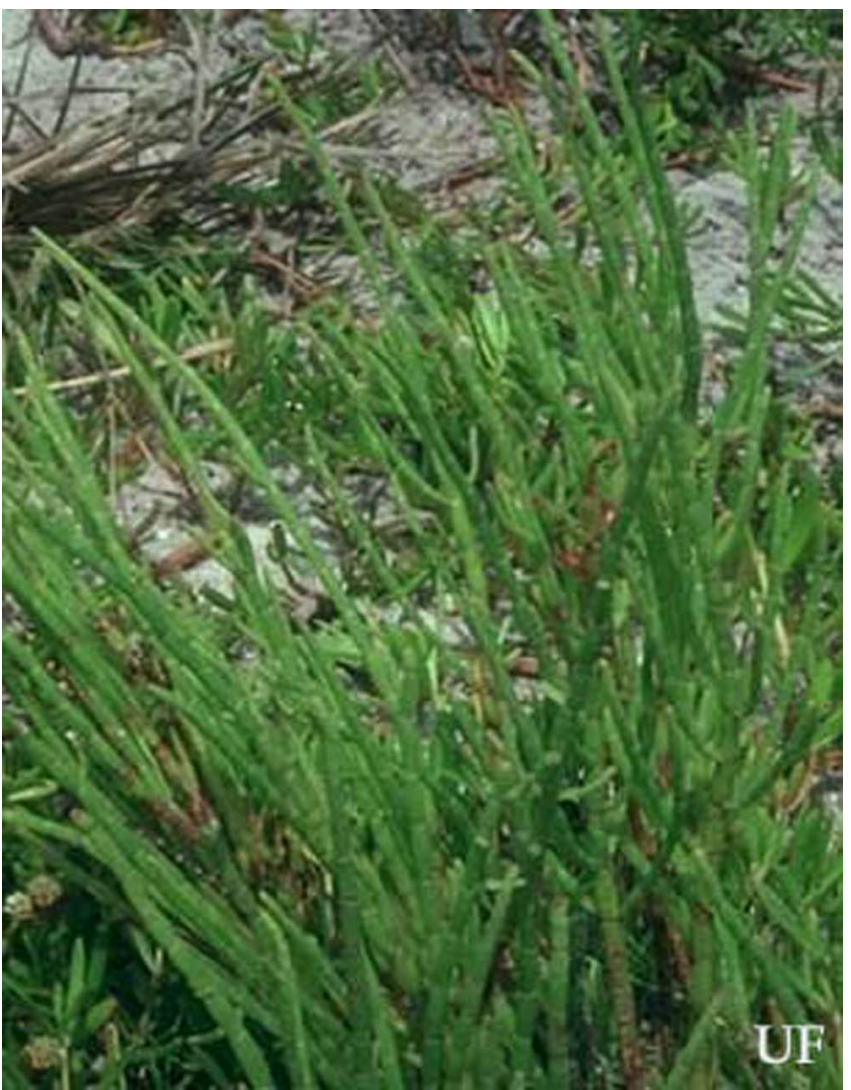

Figure 3. Annual glasswort, Salicornia bigelovii Torr. (Chenopodiaceae). Credits: Donald W. Hall, University of Florida

Opler, P.A. and V. Malikul. 1998. Eastern Butterflies. Peterson Field Guide Series. Houghton Mifflin Company. New York.

Scott, J.A. 1986. The Butterflies of North America. Stanford University Press. Stanford, CA. 